\title{
Properties and reactivity of $\mu$-nitrido bridged dimetal porphyrinoid complexes. How does ruthenium compare to iron?
}

DOI:

10.1007/s00775-019-01725-7

\section{Document Version}

Accepted author manuscript

Link to publication record in Manchester Research Explorer

Citation for published version (APA):

Bin Mubarak, M. Q. E., Sorokin, A. B., \& De Visser, S. (2019). Properties and reactivity of $\mu$-nitrido bridged dimetal porphyrinoid complexes. How does ruthenium compare to iron? Journal of Biological Inorganic Chemistry. https://doi.org/10.1007/s00775-019-01725-7

\section{Published in:}

Journal of Biological Inorganic Chemistry

\section{Citing this paper}

Please note that where the full-text provided on Manchester Research Explorer is the Author Accepted Manuscript or Proof version this may differ from the final Published version. If citing, it is advised that you check and use the publisher's definitive version.

\section{General rights}

Copyright and moral rights for the publications made accessible in the Research Explorer are retained by the authors and/or other copyright owners and it is a condition of accessing publications that users recognise and abide by the legal requirements associated with these rights.

\section{Takedown policy}

If you believe that this document breaches copyright please refer to the University of Manchester's Takedown Procedures [http://man.ac.uk/04Y6Bo] or contact uml.scholarlycommunications@manchester.ac.uk providing relevant details, so we can investigate your claim.

\section{OPEN ACCESS}




\section{Properties and reactivity of $\mu$-nitrido bridged}

\section{dimetal porphyrinoid complexes. How does ruthenium compare to iron?}

M. Qadri E. Mubarak, Alexander B. Sorokin, and Sam P. de Visser(凹)

M. Qadri E. Mubarak, S. P. de Visser ( $₫)$, Manchester Institute of Biotechnology and Department of Chemical Engineering and Analytical Science, The University of Manchester, 131 Princess Street, Manchester M1 7DN (United Kingdom).

Email: sam.devisser@manchester.ac.uk

A. B. Sorokin, Institut de Recherches sur la Catalyse et l'Environnement de Lyon (IRCELYON), UMR 5256, CNRS-Université Lyon 1, 2, av. A. Einstein, 69626 Villeurbanne Cedex (France).

Email: alexander.sorokin@ircelyon.univ-lyon1.fr 
Abstract: Methane hydroxylation by metal-oxo oxidants is one of the Holy Grails in biomimetic and biotechnological chemistry. The only enzymes known to perform this reaction in Nature are ironcontaining soluble methane monooxygenase and copper-containing particulate methane monooxygenase. Furthermore, few biomimetic iron-containing oxidants have been designed that can hydroxylate methane efficiently. Recent studies reported that $\mu$-nitrido bridged diiron(IV)-oxo porphyrin and phthalocyanine complexes hydroxylate methane to methanol efficiently. To find out whether the reaction rates are enhanced by replacing iron by ruthenium we performed a detailed computational study. Our work shows that the $\mu$-nitrido bridged diruthenium(IV)-oxo reacts with methane via hydrogen atom abstraction barriers that are considerably lower in energy (by about 5 kcal $\mathrm{mol}^{-1}$ ) as compared to the analogous diiron(IV)-oxo complex. An analysis of the electronic structure implicates similar spin and charge distributions for the diiron(IV)-oxo and diruthenium(IV)-oxo complexes, but the strength of the $\mathrm{O}-\mathrm{H}$ bond formed during the reaction is much stronger for the latter. As such a larger hydrogen atom abstraction driving force for the Ru complex than for the Fe complex is found, which should result in higher reactivity in the oxidation of methane.

Keywords: biomimetic models; methane oxidation; $\mu$-nitrido complexes; high-valent oxo species; phthalocyanine; porphyrin

Abbreviations: Density functional theory, DFT; Compound I, Cpd I; Bond dissociation energy, BDE; Electron affinity, EA; Ionization energy, IE 


\section{Introduction}

Heme monoxygenases are common enzymes in biology with a variety of functions related to biosynthesis and biodegradation. In general, they react through oxygen atom transfer to substrates on an iron(III)-heme co-factor that binds molecular oxygen, but uses two reduction and two protonation equivalents in the catalytic cycle. The most extensively studied heme monoxygenases are the cytochromes P450, which initiate the biodegradation of drug molecules in the liver as well as the biosynthesis of hormones [1-10]. During their catalytic cycle the iron(III)-heme reacts with molecular oxygen and using two external electrons and protons a high-valent iron(IV)-oxo heme cation radical species called Compound I (Cpd I) is formed [11-13]. Although Cpd I is able to hydroxylate a large range of aliphatic and aromatic $\mathrm{C}-\mathrm{H}$ bonds, it is not known to hydroxylate methane, which has the strongest $\mathrm{C}-\mathrm{H}$ bond in nature. However, work of Sorokin and co-workers on biomimetic porphyrin and

phthalocyanine complexes (Scheme 1) found evidence of methane hydroxylation by $\mu$-nitrido bridged diiron(oxo) porphyrin and phthalocyanine [14-16] and as such these complexes are unique and highly reactive in particular the supramolecular diiron phthalocyanine-porphyrin conjugates $[17,18]$. In previous work the synthesis of several $\mu$-nitrido bridged diiron(III) phthalocyanine and porphyrin complexes was reported and using terminal oxidants such as hydrogen peroxide or $m$-chloroperbenzoic acid they were converted to a $\mu$-nitrido bridged diiron(IV)-oxo species [19]. These short-lived intermediates were efficient in a reaction with aliphatic substrates (cyclohexane, adamantane and ethylbenzene) leading to substrate hydroxylation [19]. Furthermore, methane hydroxylation to methanol was observed with several complexes, which implicates that these oxidants are more powerful than cytochrome P450 Cpd I [20,21]. 


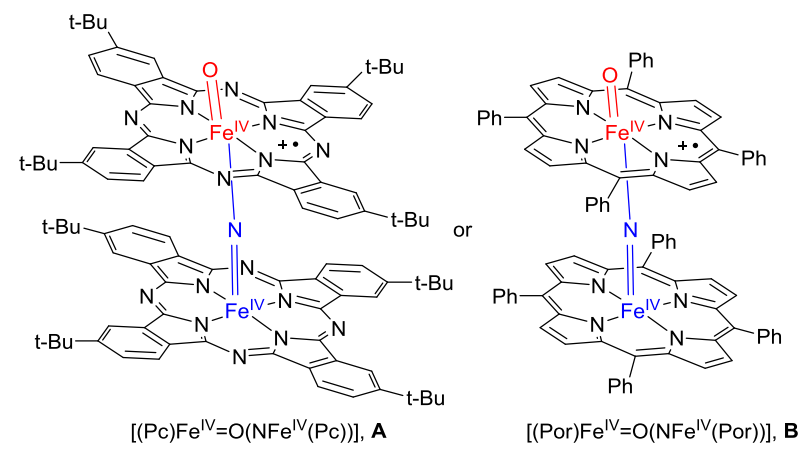

Figure 1: Examples of $\mu$-nitrido bridged diiron(IV)-oxo phthalocyanine (Pc, left) and porphyrin (Por, right) complexes.

Unprecedented reactivity of $\mu$-nitrido diiron tetrapyrrolic complexes has initiated synthetic development of this platform involving different metals supported by various macrocyclic ligands [17,18,22-27]. In parallel, several detailed computational studies on $\mu$-nitrido bridged diiron(IV)-oxo phthalocyanine and porphyrin complexes have been reported by us and others [28-32]. In general, these studies showed that the electron-donating ability of the $\mu$-nitrido group lowers the acidity of the corresponding iron-hydroxo species and consequently the strength of the $\mathrm{O}-\mathrm{H}$ bond of the iron(III)hydroxo group is large. As the driving force for a hydrogen atom abstraction reaction is larger when a stronger $\mathrm{O}-\mathrm{H}$ bond is formed [33-35] this implies that a significant enhancement of the rate constant for hydrogen atom abstraction will be observed. In this context, it is of great interest to probe how the nature of metal sites might influence on the catalytic properties of $\mu$-nitrido binuclear construction. To gain further insight into the properties and reactivities of $\mu$-nitrido bridged dimetal-oxo porphyrins and phthalocyanines we decided to create the analogous diruthenium complexes and compare the structure, electronic properties and catalysis with the diiron complexes. We predict that these diruthenium(IV)oxo phthalocyanine complexes if they can be formed will react with methane even more efficiently than their corresponding iron complexes.

\section{Methods}


The work presented here uses computational methods and procedures as reported and discussed previously on biomimetic model complexes that reproduced experimental data well [36,37]. Overall, density functional theory (DFT) approaches were used as implemented in the Gaussian-09 program package [38]. The full potential energy profile was calculated with two unrestricted DFT methods, namely the hybrid density functional method UB3LYP $[39,40]$ and the pure density functional UBP86 [41,42], for all geometry optimizations, geometry scans and frequencies. Geometry optimizations and potential energy scans were performed with a double- $\zeta$ quality LACVP basis set (with core potential) on ruthenium and $6-31 \mathrm{G}$ on the rest of the atoms, basis set BS1 [43,44]. All local minima and transition states were optimized without constraints and characterized with an analytical frequency that confirmed the status of the structures with all transition states having a single imaginary frequency for the correct mode. Calculations include a polarized continuum model (CPCM) as implemented in Gaussian using a dielectric constant of $\varepsilon=35.688$ mimicking acetonitrile. Energies were improved through a single point calculation with an LACV3P+ (with core potential) basis set on ruthenium and 6-311+G* on the rest of the atoms: basis set BS2. These methods were used previously and reproduced experimentally determined free energies of activation and kinetic isotope effects well $[45,46]$. In the past we validated our computational methods and showed that these procedures can reproduce experimental free energies of activation to within $3 \mathrm{kcal} \mathrm{mol}^{-1}$. Moreover, changing the basis set for geometry optimizations from BS1 to BS2 gave little changes to the optimized geometries, relative energies and chemoselectivities of the reaction [47-49]. Finally, the effect of dispersion on the optimized geometries of $\mu$-nitrido bridged diiron(IV)-oxo porphyrins was tested for the defluorination reaction of $\mathrm{C}_{6} \mathrm{~F}_{6}$ and found to give little changes in geometry and energetics and hence dispersion was not used in this work [50].

\section{Results and Discussion}

In this work, we focus on the chemical properties of the $\mu$-nitrido bound diruthenium(IV)-oxo porphyrazine $(\mathrm{Pz})$ complex ${ }^{2,4,6}\left[\mathrm{O}=\mathrm{Ru}^{\mathrm{IV}}\left(\mathrm{Pz}^{+\bullet}\right) \mathrm{NFe}^{\mathrm{IV}}(\mathrm{Pz})\right]^{0}\left(\right.$ or $\left.^{2,4,6}\left[\mathrm{O}=\mathrm{Ru}^{\mathrm{V}}(\mathrm{Pz}) \mathrm{NFe}^{\mathrm{IV}}(\mathrm{Pz})\right]^{0}\right), \mathbf{1}$, whereby 
all side chains of the macrocycle are abbreviated to hydrogen atoms. The complex is charge neutral and was calculated in all low lying doublet, quartet and sextet spin states using two density functional theory methods (UB3LYP and UBP86). In addition, the reactivity patterns of the complexes with methane was compared with the analogous diiron(IV)-oxo complex ${ }^{2,4,6} \mathbf{2}$ reported previously [29-31].

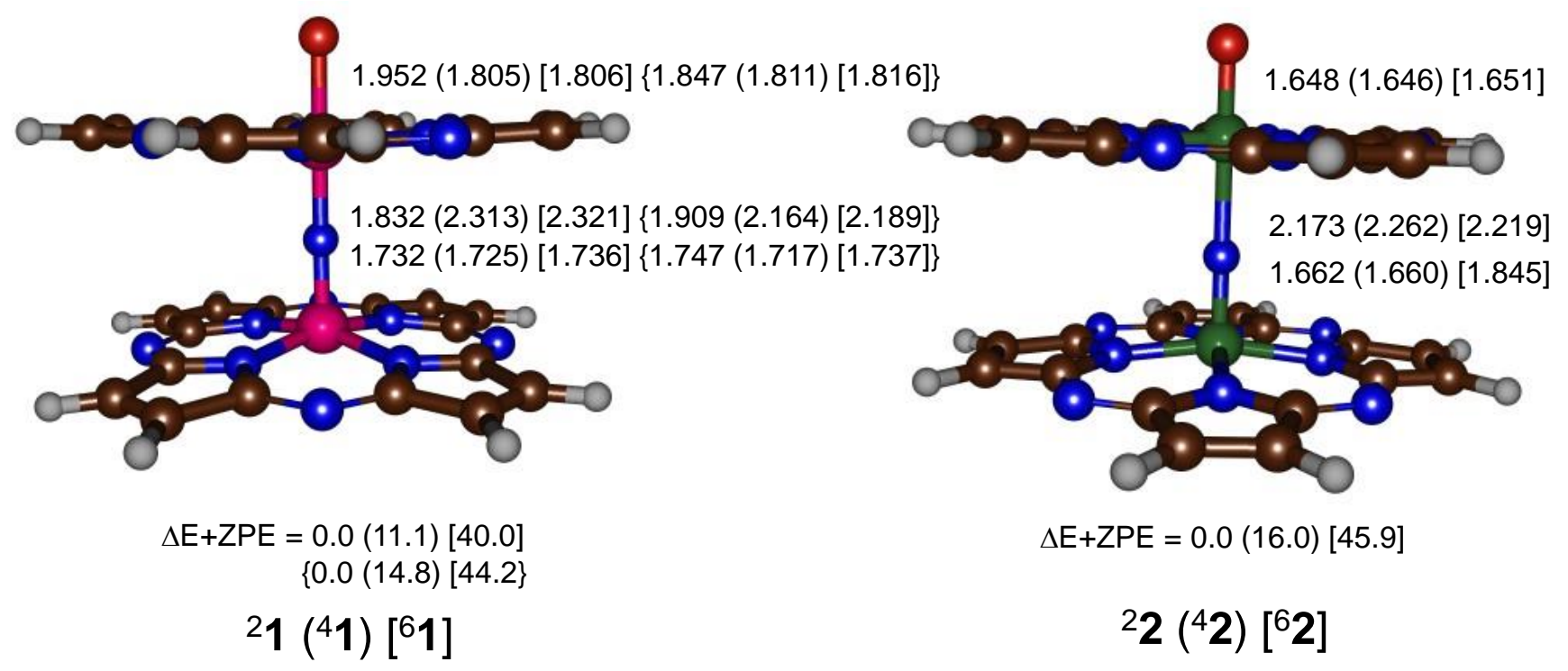

Figure 2: Optimized geometries of ${ }^{2,4,6} \mathbf{1}$ (left-hand-side) and ${ }^{2,4,6} \mathbf{2}$ (right-hand-side) as obtained in Gaussian-09 at UB3LYP/BS1 (UPB86/BS1). Bond lengths are in angstroms and relative energies (calculated with BS2 basis set with zero-point energy (ZPE) correction) in kcal mol ${ }^{-1}$. Data for ${ }^{2,4,6} \boldsymbol{2}$ taken from Ref [29].

Before we show the results on the catalytic properties of oxidant ${ }^{2,4,6} \mathbf{1}$, let us investigate the electronic and structural properties of the reactant species in more detail. Figure 2 displays the optimized geometries and relative energies of ${ }^{2,4,6} \mathbf{1}$. In both complexes the doublet spin state is the ground state and well separated from the quartet and sextet spin states by at least $10 \mathrm{kcal} \mathrm{mol}^{-1}$. This is independent on the density functional method chosen and implicates that the quartet and sextet spin states will play no role in catalysis. As such the reactivity with substrates is expected to take place on the doublet spin state only and the oxidants will react through single-state-reactivity [51,52] selectively. Mononuclear 
iron(IV)-oxo oxidants often have close-lying spin state surfaces, where reactivity patterns appear on multiple accessible electronic and spin states. It is not surprising that the ruthenium complexes react through single-state-reactivity patterns as $\mathrm{Ru}^{\mathrm{IV}}=\mathrm{O}$ complexes tend to have well separated metal $4 \mathrm{~d}$ orbitals and hence usually stabilize low-spin states [53-55]. Indeed previous studies on mononuclear $\mathrm{Ru}^{\mathrm{IV}}=\mathrm{O}$ complexes showed the high-spin states to be considerably higher in energy than the lower spin states [56] in agreement with what is seen here.

In structures ${ }^{2,4} 2$ the $\mathrm{Fe}_{1}-\mathrm{O}$ and $\mathrm{Fe}_{2}-\mu-\mathrm{N}$ distances were found to be about $1.65 \AA$ in length, which indicates that both bonds will be formally a double bond. In the ruthenium complexes both of these bonds have significantly elongated with respect to those of the diiron complexes as expected for a heavier element. However, the $\mathrm{Ru}_{1}-\mathrm{O}$ distances are significantly longer than the $\mathrm{Ru}_{2}-\mu-\mathrm{N}$ distances, which implicates that they have different bonding character. Furthermore, the ruthenium atom of the $\mathrm{Ru}_{1}-\mathrm{O}$ group is located below the plane through the four nitrogen atoms of the equatorial ligand, while in the iron complexes the $\mathrm{Fe}_{1}$ atom remains above the plane. Finally, particularly in the low-spin state the bridging nitrogen atom is close to the center of the $\mathrm{Ru}_{1}-\mathrm{Ru}_{2}$ interaction, whereas in the corresponding diiron(IV)-oxo species it is closer to $\mathrm{Fe}_{2}$ than to $\mathrm{Fe}_{1}$.

To understand the differences in geometry between the diiron and diruthenium complexes we analyzed the molecular orbitals, which are displayed in Figure 3 . The orbitals are dominated by the $\pi$ interactions in the $\mathrm{xz}$ and yz molecular planes, where we take the $\mathrm{z}$-axis along the $\mathrm{Ru}-\mathrm{O}$ bond. Thus, the $4 \mathrm{~d}_{\mathrm{xz}}$ and $4 \mathrm{~d}_{\mathrm{yz}}$ atomic orbitals on both $\mathrm{Ru}$ atoms interact with the $2 \mathrm{p}_{\mathrm{x}}$ and $2 \mathrm{p}_{\mathrm{y}}$ atomic orbitals on the oxo and bridging nitrogen atoms to form four sets of orbitals: $\pi_{1, \mathrm{x}} / \pi_{1, \mathrm{y}} \pi_{2, \mathrm{x}} / \pi_{2, \mathrm{y}} \pi^{*}{ }_{3, \mathrm{x}} / \pi^{*}{ }_{3, \mathrm{y}} \pi_{4, \mathrm{x}} / \pi^{*}{ }_{4, \mathrm{y}}$. The lowest two sets of orbitals represent the bonding interactions for the $\mathrm{Ru}-\mathrm{O}$ and $\mathrm{Ru}-\mathrm{N}$ interaction. The $\pi_{3, \mathrm{x}}$ and $\pi_{3, \mathrm{y}}$ orbitals have a bonding interaction between the top $\mathrm{Ru}$ atom and the axial ligand but are antibonding for the $\mathrm{Ru}-\mathrm{O}$ and $\mathrm{Ru}-\mathrm{N}$ interactions. The doublet spin state for both ${ }^{2} \mathbf{1}$ and ${ }^{2} \mathbf{2}$ has orbital occupation $\pi_{1, \mathrm{x}}{ }^{2} \pi_{1, \mathrm{y}}{ }^{2} \pi_{2, \mathrm{x}}{ }^{2} \pi_{2, \mathrm{y}}{ }^{2} \pi^{*}{ }_{3, \mathrm{x}}{ }^{2} \pi^{*}{ }_{3, \mathrm{y}}{ }^{1} \pi^{*}{ }_{4, \mathrm{x}}{ }^{0} \pi^{*}{ }_{4, \mathrm{y}}{ }^{0}$. These orbital occupations are quite different from typical mononuclear heme complexes, i.e. $\mathrm{Fe}^{\mathrm{IV}}=\mathrm{O}\left(\right.$ heme $\left.^{+\bullet}\right)$ or $\mathrm{P} 450 \mathrm{Cpd} \mathrm{I}$, that have a heme radical 
with singly occupied $\mathrm{a}_{2 u}$ orbital. In the $\mu$-nitrido bridged complexes, by contrast, the $\mathrm{a}_{2 u}$ orbitals are lower in energy and are doubly occupied.
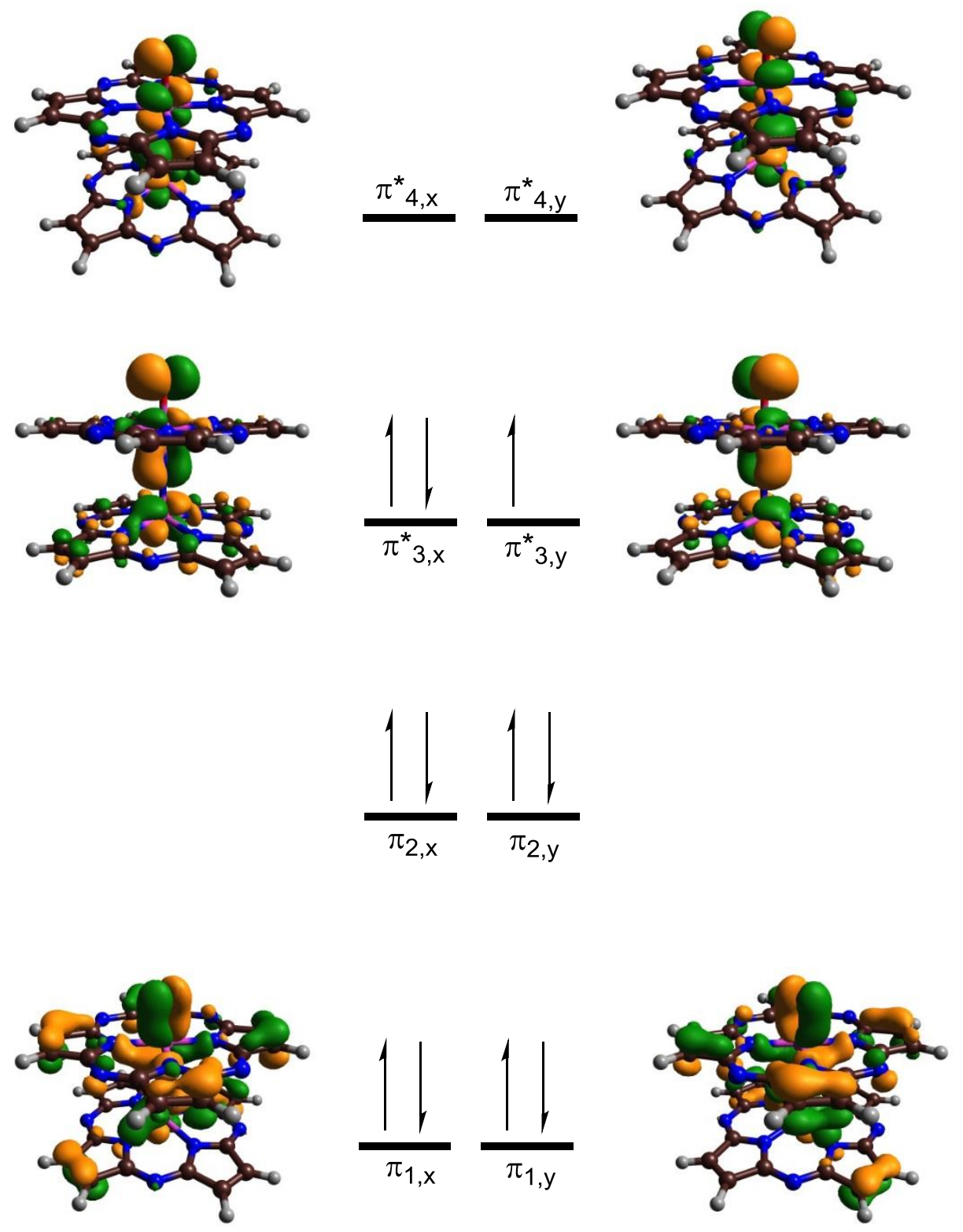

Figure 3: High-lying occupied and low-lying virtual orbitals of ${ }^{2} \mathbf{1}$.

Group spin densities of the doublet spin state reactants give dominant oxo radical character $\left(\rho_{\mathrm{O}}=0.90\right.$ at UB3LYP and 0.56 for the UBP86 calculation). Nevertheless, in both cases the radical refers to a singly occupied $\pi_{3, y}^{*}$ molecular orbital. These two results give $S^{2}$ values of 0.792 and 0.775 and hence include very little multiconfiguration perturbations. 
Subsequently, we investigated methane hydroxylation by ${ }^{2,4,6} \mathbf{1}$ and ${ }^{2,4,6} \boldsymbol{2}$ and the results are depicted in Figure 4. Similar to methane hydroxylation by iron(IV)-oxo complexes [57-63] the reaction is stepwise with an initial hydrogen atom abstraction (via transition state $\left.\mathbf{T} \mathbf{S}_{\mathrm{HA}}\right)$ to form a radical intermediate $\left(\mathbf{I}_{\mathrm{HA}}\right)$. Thereafter, an $\mathrm{OH}$ rebound barrier (via transition state $\mathbf{T S} \mathbf{S}_{\mathrm{reb}}$ ) gives alcohol product complexes $\left(\mathbf{P}_{\mathrm{HA}}\right)$. The free energies obtained with B3LYP and BP86 are very similar particularly for the transition states and also analogous structures are found. Therefore, the density functional method appears to have little effect on the structure and energies of the reaction mechanism. This contrast the spin-state ordering and relative energies of mononuclear iron and manganese-oxo complexes that often give strong variations depending on the density functional method chosen and particularly the amount of Hartree-Fock Exchange that is included in the method $[45,64,65]$. In all cases the doublet spin state is well below the quartet and sextet spin state and hence the reaction takes place via single-state-reactivity on the doublet spin state surface and no spin crossing to another spin state is expected. Thus, the doublet spin hydrogen atom abstraction barrier is $7.8(10.2) \mathrm{kcal} \mathrm{mol}^{-1}$ above isolated reactants as calculated with UB3LYP (UBP86), while the quartet spin barriers are at $30.0(32.0) \mathrm{kcal} \mathrm{mol}^{-1}$ and the sextet spin ones at 57.7 (61.8) $\mathrm{kcal} \mathrm{mol}^{-1}$. At room temperature the quartet and sextet barriers will be inaccessible and the reaction will take place on a dominant doublet spin state only. Therefore, we focus on the doublet spin results from Figure 4 in the following only. 


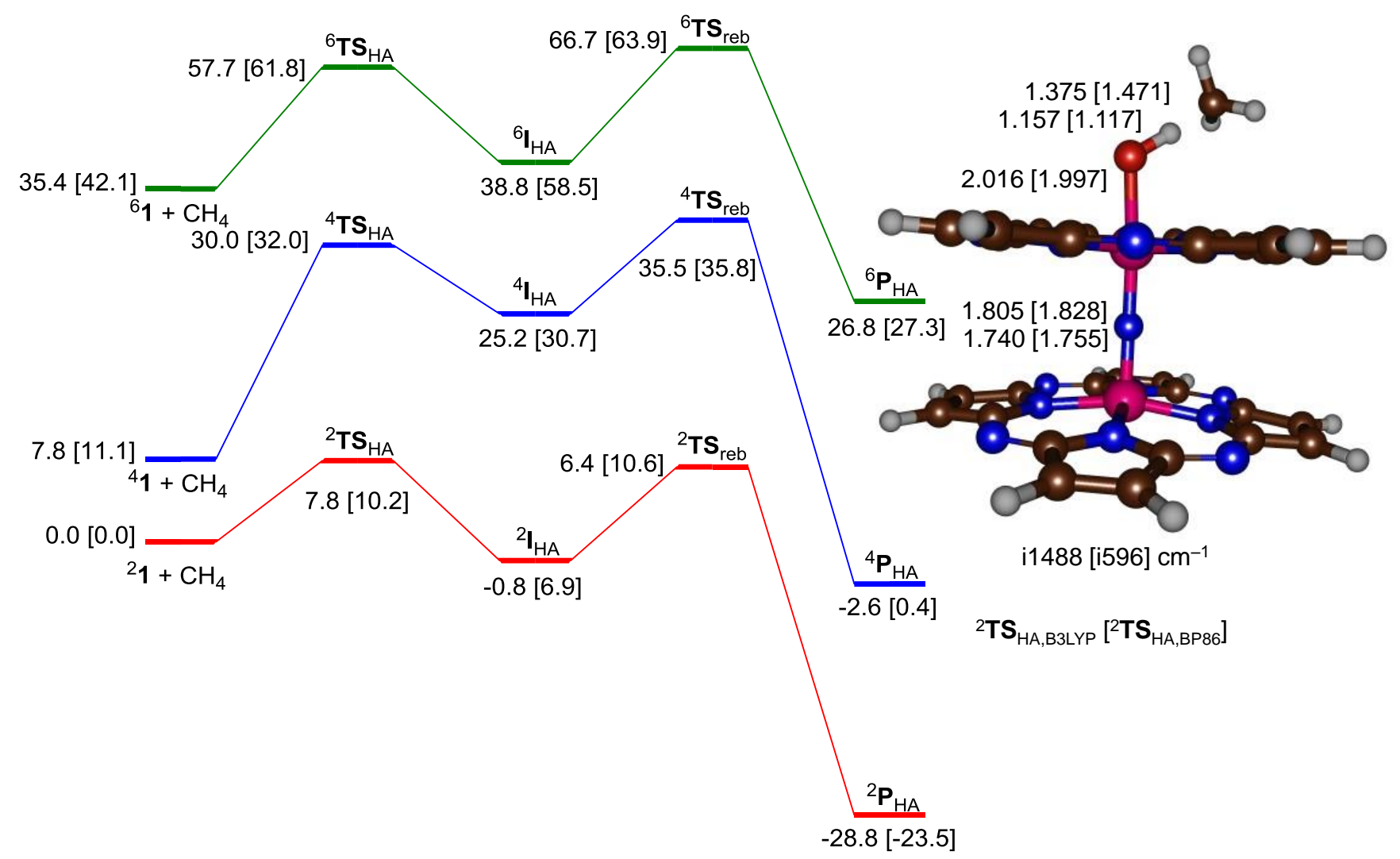

Figure 4: Potential energy landscape of methane hydroxylation by ${ }^{2,4,6} \mathbf{1}$ as obtained with DFT. Data obtained through full geometry optimization with UB3LYP [UBP86] level of theory. Free energies (at BS2 level of theory) are in $\mathrm{kcal} \mathrm{mol}^{-1}$ with solvent, thermal, entropic and ZPE corrections included. Optimized geometries give bond lengths in angstroms and the imaginary frequency in $\mathrm{cm}^{-1}$.

Optimized geometries of the rate determining doublet spin transition states $\left({ }^{2} \mathbf{T} \mathbf{S}_{\mathrm{HA}}\right)$ are given in Figure 4. The transition states are late with long $\mathrm{C}-\mathrm{H}$ distances (1.375 and 1.471 $\AA$ at B3LYP and BP86 level of theory) and short O-H distances (1.157 and 1.117 $\AA$ at B3LYP and BP86 level of theory). Late transition states often related to high energy barriers. Thus, for a series of hydrogen atom abstraction barriers by the same metal(IV)-oxo oxidant it was shown that the barrier height correlated with the strength of the $\mathrm{C}-\mathrm{H}$ bond that was broken $[58,59,66,67]$. It was found that reactions with substrates with strong $\mathrm{C}-\mathrm{H}$ bonds gave more product-like transition states, whereas with substrates with weak $\mathrm{C}-\mathrm{H}$ bonds more reactant-like transition states were found. As methane has a strong $\mathrm{C}-\mathrm{H}$ bond strength with 
bond dissociation energy $\left(\mathrm{BDE}_{\mathrm{CH} \text {,methane }}=101.6 \mathrm{kcal} \mathrm{mol}^{-1}\right.$ at UB3LYP level of theory) it is not surprising that the hydrogen atom abstraction barriers are high.

The rate-determining step in the reaction mechanism is hydrogen atom abstraction with a free energy of activation of $7.8 \mathrm{kcal} \mathrm{mol}^{-1}$, which is well lower in free energy here than that found for the analogous $\mu$-nitrido bridged diiron(IV)-oxo phthalocyanine complexes reported before [29], where a value of 15.7 $\mathrm{kcal} \mathrm{mol}^{-1}$ was found. Therefore, the diruthenium complex is expected to react with hydrogen atom abstraction barriers that are almost $8 \mathrm{kcal} \mathrm{mol}^{-1}$ lower in free energy, which would correspond to a rate enhancement of over $10^{6}$. Clearly, the diruthenium(IV)-oxo species is a considerably better oxidant that the corresponding diiron(IV)-oxo species. We will analyze the differences in structure and reactivity in detail in the following. Note that the rebound barrier is $7.2(3.7) \mathrm{kcal} \mathrm{mol}^{-1}$ in energy above the radical intermediate ${ }^{2} \mathbf{I}_{\mathrm{HA}}$ as calculated at UB3LYP (UPB86) level of theory. These barriers are considerable and may implicate a finite lifetime of the radical intermediates, which in the case of ethene activation by iron(IV)-oxo complexes was shown to lead to by-products $[68,69]$. Furthermore, the radical could be released from the intermediate complex as dissipate into solution as suggested for nonheme iron reactivities [70].

21

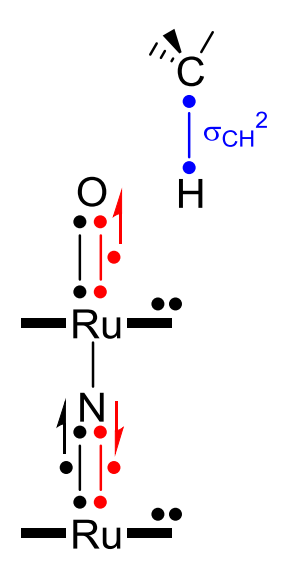

${ }^{2} \mathbf{I}_{\mathrm{HA}}$

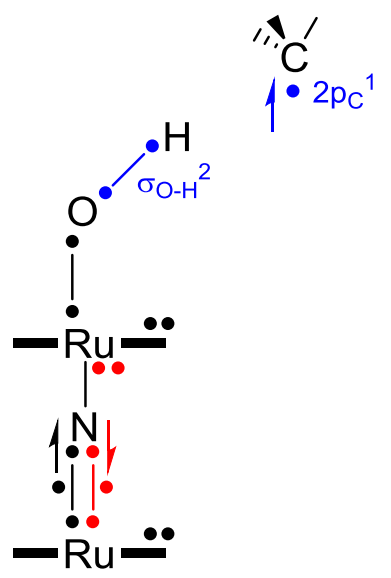

${ }^{2} \mathbf{P}_{\mathrm{HA}}$
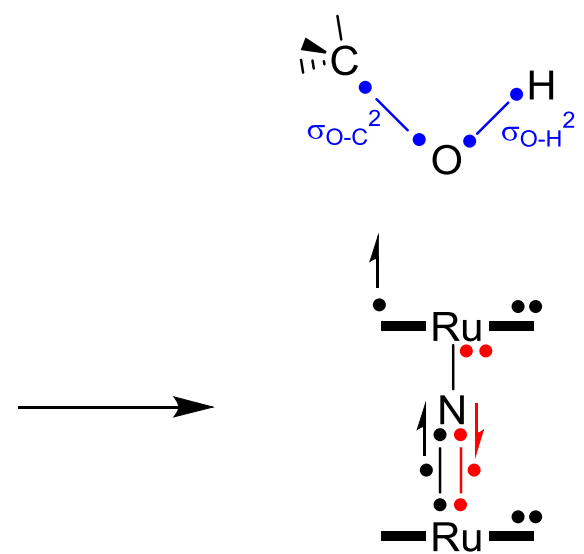

Figure 5: Orbital occupation changes along the doublet spin reaction mechanism in Valence Bond description. 
Figure 5 gives the orbital energy changes during the methane hydroxylation reaction on the doublet spin state in a valence bond description. Thus, we describe electrons as a dot and a line bordered by two dots in a bonding orbital occupied by two electrons. These schemes were used previously to rationalize regioselectivities as electronic configurations of oxidants [34,71-73]. As mentioned above in Figure 3 the $\mu$-nitrido bridged diruthenium(IV)-oxo complex has electronic configuration of $\pi_{3, \mathrm{x}}^{*} \pi^{*}{ }_{3, \mathrm{y}}{ }^{1}$. Upon abstraction of a hydrogen atom from substrate, a $\sigma_{\mathrm{CH}}$ bond of methane is broken and splits into atomic orbitals: $2 \mathrm{p}_{\mathrm{C}}$ and $1 \mathrm{~s}_{\mathrm{H}}$. The hydrogen atom pairs up with one electron from the $\pi_{3, \mathrm{y}}^{*}$ molecular orbital to form the $\sigma_{\mathrm{O}-\mathrm{H}}$ orbital with two electrons, while the $\pi_{\mathrm{y}}$ set of orbitals splits into a new set of three orbitals $\left(\pi_{1, y}^{\prime} \pi_{2, y}^{\prime} \pi^{*}{ }_{3, y}\right)$ that only spread over the $\mathrm{Ru}, \mathrm{N}$ and $\mathrm{Ru}$ atoms and contain four electrons. During the $\mathrm{OH}$ rebound process also the $\pi$ orbitals along the $\mathrm{x}$-axis lose the oxygen contribution and split into a new set of orbitals $\pi_{1, \mathrm{x}}^{\prime} \pi_{2, \mathrm{x}}^{\prime} \pi^{*}{ }_{3, \mathrm{x}}$ with four electrons. One electron from the $\mathrm{Ru}-\mathrm{O}$ interaction pairs up with the radical on the $\mathrm{CH}_{3}$ group to form the new $\sigma_{\mathrm{O}-\mathrm{C}}$ orbital, whereas the second one is promoted to a virtual $\pi$ orbital on the porphyrazine group. As a consequence the product has spin density on the ligand but not on the metals.

We also did a thermochemical analysis on the hydrogen atom and electron abstraction ability of the $\mu$ nitrido-bridged diiron and diruthenium-oxo complexes, see Figure 6. First we calculated the bond dissociation energy of the $\mathrm{O}-\mathrm{H}$ bond $\left(\mathrm{BDE}_{\mathrm{OH}}\right)$ in the $\mathrm{M}^{\mathrm{IV}}(\mathrm{OH})$ complex $(\mathrm{M}=\mathrm{Fe}, \mathrm{Ru})$ as defined in $\mathrm{Eq}$ 1 , where we compare the energy of the $\mathrm{M}^{\mathrm{IV}}(\mathrm{OH})$ complex relative to that of the $\mathrm{M}^{\mathrm{IV}}=\mathrm{O}$ complex and a separate hydrogen atom. For the iron complex a value of $86.7 \mathrm{kcal} \mathrm{mol}^{-1}$ was reported for the structure without axial ligand and $82.3 \mathrm{kcal} \mathrm{mol}^{-1}$ when an axial acetate was present [29]. Interestingly, using the same methods and techniques a value of $134.9 \mathrm{kcal} \mathrm{mol}^{-1}$ is found for the $\mathrm{Ru}^{\mathrm{IV}}(\mathrm{OH})$ system. Therefore, based on the relative $\mathrm{BDE}$ values, the $\mu$-nitrido bridged diruthenium-oxo complex is expected to be a considerably better oxidant than the corresponding iron complex and should react with methane even faster. The relative energies of the hydrogen atom abstraction transition states discussed above indeed confirm this. 


$$
\mathrm{M}^{\mathrm{IV}}(\mathrm{OH}) \rightarrow \mathrm{M}^{\mathrm{IV}}=\mathrm{O}+\mathrm{H}^{\bullet}+\mathrm{BDE}_{\mathrm{OH}}
$$

Technically, a hydrogen atom abstraction is the sum of a proton transfer and an electron transfer; therefore, we split the $\mathrm{BDE}_{\mathrm{OH}}$ further into the sum of the acidity of the reduced oxidant $\left(\Delta \mathrm{G}_{\text {acid }}\right)$, the electron affinity (EA) of the starting complex and the ionization energy of a hydrogen atom $\left(\mathrm{IE}_{\mathrm{H}}\right)$. The latter was taken from the literature [74]. Interestingly, the acidity of the iron and ruthenium-hydroxo complexes are alike and the differences in electron affinity compensates for stronger $\mathrm{O}-\mathrm{H}$ bond formation. As a particularly strong $\mathrm{O}-\mathrm{H}$ bond is formed after hydrogen atom abstraction this results in a large driving force for hydrogen atom abstraction and consequently low energy hydrogen atom abstraction barriers.
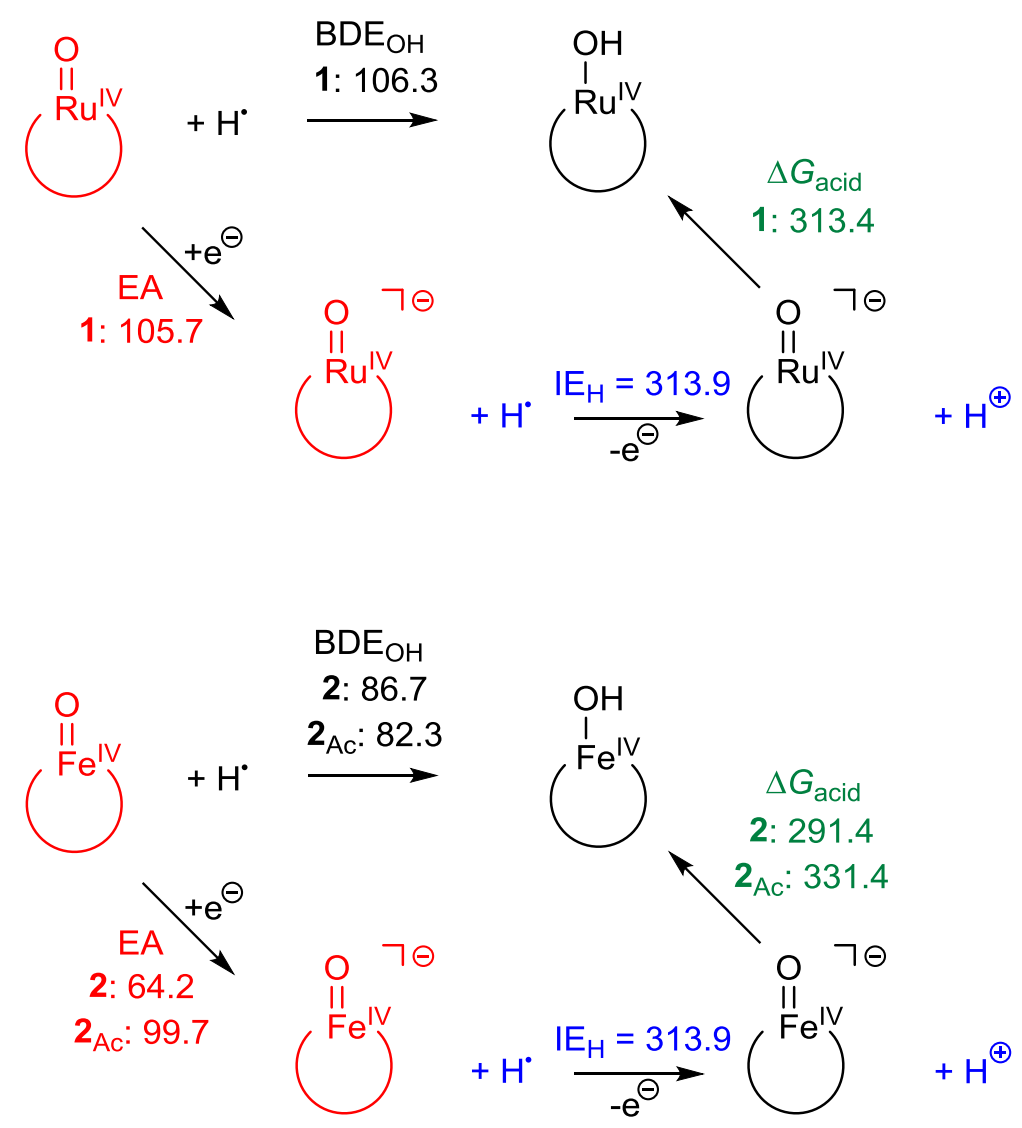

Figure 6: Thermochemical analysis of hydrogen atom abstraction, proton transfer and electron transfer ability of the iron(IV)-oxo versus ruthenium(IV)-oxo complexes. Values are in kcal mol ${ }^{-1}$. 


\section{Conclusions}

Computational studies on a $\mu$-nitrido bridged diruthenium(IV)-oxo porphyrazine complex were performed and its reactivity with methane investigated. Our studies show that the complex is in a doublet spin ground state that is well separated from other spin states and with significant radical character on the oxo group. The electronic configuration of the $\mu$-nitrido bridged diruthenium(IV)-oxo complex is analogous to the corresponding diiron complex; however, it reacts with substrate with considerably lower barriers due to a more favorable hydrogen atom abstraction reaction. These differences are rationalized with thermochemical cycles and valence bond schemes.

Acknowledgements MQEM thanks the Government of Malaysia for a studentship. The EU-COST Network for Bioinorganic Reaction Mechanisms (CM1003) is acknowledged for support. ABS is grateful to ANR, France for support (grant ANR-16-CE29-0018-01).

Supporting Information. Raw data, including absolute and relative energies, group spin densities and charges and Cartesian coordinates of all optimized geometries in this work are supplied as Supporting Information.

Conflict of Interest: The authors declare that they have no conflict of interest.

\section{References}

1. Sono M, Roach MP, Coulter ED, Dawson JH (1996) Chem Rev 96: 2841-2888. DOI: $10.1021 / \mathrm{cr} 9500500$.

2. Groves JT (2003) Proc Natl Acad Sci USA 100: 3569-3574. DOI: 10.1073/pnas.0830019100. 
3. Ortiz de Montellano PR (2004) (ed) Cytochrome P450: Structure, Mechanism and Biochemistry, 3rd ed. Kluwer Academic/Plenum Publishers, New York.

4. Meunier B, de Visser SP, Shaik S (2004) Chem Rev 104: 3947-3980. DOI: 10.1021/cr020443g.

5. Denisov IG, Makris TM, Sligar SG, Schlichting I (2005) Chem Rev 105: 2253-2277. DOI: $10.1021 / \mathrm{cr} 0307143$.

6. Kadish KM, Smith KM, Guilard R (2010) (eds) Handbook of Porphyrin Science, World Scientific Publishing Co., New Jersey.

7. Ortiz de Montellano PR (2010) Chem Rev 110: 932-948. DOI: 10.1021/cr9002193.

8. Grogan G (2011) Curr Opin Chem Biol 15: 241-248. DOI: 10.1016/j.cbpa.2010.11.014.

9. Poulos TL (2014) Chem Rev 114: 3919-3962. DOI: dx.doi.org/10.1021/cr400415k.

10. Huang X, Groves JT (2018) Chem Rev 118: 2491-2553. DOI: 10.1021/acs.chemrev.7b00373.

11. Rittle J, Green MT (2010) Science 330: 933-937. DOI: 10.1126/science.1193478.

12. Ogliaro F, Cohen S, de Visser SP, Shaik S (2000) J Am Chem Soc 122: 12892-12893. DOI: 10.1021/ja005619f.

13. Shaik S, Kumar D, de Visser SP, Altun A, Thiel W (2005) Chem Rev 105: 2279-2328. DOI: $10.1021 / \mathrm{cr} 030722 \mathrm{j}$.

14. Sorokin AB, Kudrik EV, Bouchu D (2008) Chem Commun: 2562-2564. DOI: 10.1039/B804405H.

15. Sorokin AB, Kudrik EV, Alvarez LX, Afanasiev P, Millet JMM, Bouchu D (2010) Catal Today 157: 149-154. DOI: 10.1016/j.cattod.2010.02.007.

16. Sorokin AB (2013) Chem Rev 113: 8152-8191. DOI: 10.1021/cr4000072.

17. Yamada Y, Morita K, Mihara N, Igawa K, Tomooka K, Tanaka K (2019) New J Chem 43: 11477-11482. DOI: 10.1039/c9nj02210d.

18. Mihara N, Yamada Y, Takaya H, Kitagawa Y, Igawa K, Tomooka K, Fujii H, Tanaka K (2019) Chem Eur J 25: 3369-3375. DOI: 10.1002/chem.201805580.

19. Afanasiev P, Sorokin AB (2016) Acc Chem Res 49: 583-593. DOI: 10.1021/acs.accounts.5b00458.

20. Kudrik EV, Afanasiev P, Alvarez LX, Dubourdeaux P, Clémancey M, Latour J-M, Blondin G, Bouchu D, Albrieux F, Nefedov SE, Sorokin AB (2012) Nat Chem 4: 1024-1029. DOI: 10.1038/nchem.1471.

21. Colomban C, Kudrik EV, Afanasiev P, Sorokin AB (2014) J Am Chem Soc 136: 11321-11330. DOI: $10.1021 / \mathrm{ja} 505437 \mathrm{~h}$.

22. So S-C, Cheung W-M, Chiu W-H, de Vere-Tucker M, Sung HH-Y, Williams ID, Leung W-H (2019) Dalton Trans 48: 8340-8349. DOI: 10.1039/c9dt00244h.

23. Cheung W-M, Ng W-M, Wong W-H, Lee HK, Sung HH-Y, Williams ID, Leung W-H (2018) Inorg Chem 57: 9215-9222. DOI: 10.1021/acs.inorgchem.8b01229. 
24. Cheung W-M, Chiu W-H, de Vere-Tucker M, Sung HH-Y, Williams ID, Leung W-H (2017) Inorg Chem 56: 5680-5687. DOI: 10.1021/acs.inorgchem.7b00281.

25. Stuzhin PA, Ivanova SS, Dereven'kov I, Makarov SV, Silaghi-Dumitrescu R, Homborg H (2012) Macroheterocycles 5: 175-177. DOI/ 10.6060/mhc2012.120360s.

26. Colomban C, Kudrik EV, Sorokin AB (2017) J Porphyrins Phthalocyanines 21: 345-353. DOI: 10.1142/S1088424617500274.

27. İşci Ü, Dumoulin F, Sorokin AB, AhsenV (2014) Turk J Chem 38: 923-949. DOI: 10.3906/kim1407-47.

28. İşci Ü, Faponle AS, Afanasiev P, Albrieux F, Briois V, Ahsen V, Dumoulin F, Sorokin AB, de Visser SP (2015) Chem Sci 6: 5063-5075. DOI: 10.1039/c5sc01811k.

29. Quesne MG, Senthilnathan D, Singh D, Kumar D, Maldivi P, Sorokin AB, de Visser SP (2016) ACS Catal 6: 2230-2243. DOI: 10.1021/acscatal.5b02720.

30. Silaghi-Dumitrescu R, Makarov SV, Uta M-M, Dereven'kov IA, Stuzhin PA (2011) New J Chem 35: 1140-1145. DOI: 10.1039/c0nj00827c.

31. Ansari M, Vyas N, Ansari A, Rajaraman G (2015) Dalton Trans 44: 15232-15243. DOI: 10.1039/C5DT01060H.

32. Phung QM, Pierloot K (2019) Chem Eur J 25: in press, DOI : 10.1002/chem.201902766.

33. Mayer JM (2004) Annu Rev Phys Chem 55: 363-390.

34. de Visser SP (2010) J Am Chem Soc 132: 1087-1097. DOI: 10.1021/ja908340j.

35. Kumar D, Sastry GN, de Visser SP (2011) Chem Eur J 17: 6196-6205.

36. de Visser SP, Quesne MG, Martin B, Comba P, Ryde U (2014) Chem Commun 50: 262-282. DOI: $10.1039 / \mathrm{c} 3 \mathrm{cc} 47148 \mathrm{a}$.

37. Kumar S, Faponle AS, Barman P, Vardhaman AK, Sastri CV, Kumar D, de Visser SP (2014) J Am Chem Soc 136: 17102-17115. DOI: 10.1021/ja508403w.

38. Frisch MJ (2013) Gaussian-09, revision C.02, Gaussian Inc, Wallingford CT.

39. Becke AD (1993) J Chem Phys 98: 5648-5652. DOI: 10.1063/1.464913.

40. Lee C, Yang W, Parr RG (1988) Phys. Rev. B 37: 785-789. DOI: 10.1103/PhysRevB.37.785.

41. Becke AD (1988) Phys Rev A 38: 3098-3100. DOI: 10.1103/PhysRevA.38.3098.

42. Perdew JP (1986) Phys Rev B 33: 8822-8824. DOI: 10.1103/PhysRevB.33.8822.

43. Hay PJ, Wadt WR (1985) J Chem Phys 82: 270-283. DOI: 10.1063/1.448799.

44. Ditchfield R, Hehre WJ, Pople JA (1971) J Chem Phys 54: 724-728. DOI: https://doi.org/10.1063/1.1674902.

45. Cantú Reinhard FG, Faponle AS, de Visser SP (2016) J Phys Chem A 120: 9805-9814. DOI: $10.1021 /$ acs.jpca.6b09765. 
46. Cantú Reinhard FG, Barman P, Mukherjee G, Kumar J, Kumar D, Kumar D, Sastri CV, de Visser SP (2017) J Am Chem Soc 139: 18328-18338. DOI: 10.1021/jacs.7b10033.

47. Vardhaman AK, Sastri CV, Kumar D, de Visser SP (2011) Chem Commun 47: 11044-11046.

48. Cheaib K, Mubarak MQE, Sénéchal-David K, Herrero C, Guillot R, Clémancey M, Latour J-M, de Visser SP, Mahy J-P, Banse F, Avenier F (2019) Angew Chem Int Ed 58: 854-858.

49. Barman P, Cantú Reinhard FG, Bagha UK, Kumar D, Sastri CV, de Visser SP (2019) Angew Chem Int Ed 58: 10639-10643.

50. Colomban C, Tobing AH, Mukherjee G, Sastri CV, Sorokin AB, de Visser SP (2019) Chem Eur $\mathrm{J}$ 25: in press (DOI: 10.1002/chem.201902934).

51. Hirao H, Kumar D, Que Jr L, Shaik S (2006) J Am Chem Soc 128: 8590-8606. DOI: 10.1021/ja061609o.

52. de Visser SP (2006) J Am Chem Soc 128: 15809-15818. 10.1021/ja065365j.

53. Sharma PK, de Visser SP, Ogliaro F, Shaik S (2003) J Am Chem Soc 125: 2291-2300. $10.1021 / \mathrm{ja} 0282487$.

54. Man W-L, Xie J, Pan Y, Lam WWY, Kwong H-K, Ip K-W, Yiu S-M, Lau K-C, Lau T-C (2013) J Am Chem Soc 135: 5533-5536. DOI: dx.doi.org/10.1021/ja401553d.

55. Guo Z, Guan X, Huang J-S, Tsui W-M, Lin Z, Che C-M (2013) Chem Eur J. 19: 11320-11331. DOI: $10.1002 /$ chem.201300021.

56. Dhuri SN, Seo MS, Lee Y-M, Hirao H, Wang Y, Nam W, Shaik S (2008) Angew Chem Int Ed 47: 3356-3359.

57. Ogliaro F, Harris N, Cohen S, Filatov M, de Visser SP, Shaik S (2000) J Am Chem Soc 122: 8977-8989. DOI: 10.1021/ja991878x.

58. de Visser SP, Kumar D, Cohen S, Shacham R, Shaik S (2004) J Am Chem Soc 126: 8362-8363. DOI: $10.1021 / \mathrm{ja} 048528 \mathrm{~h}$.

59. Shaik S, Kumar D, de Visser SP (2008) J Am Chem Soc 130: 10128-10140. DOI: 10.1021/ja8019615.

60. Singh D, Kumar D, de Visser SP (2015) Int J Sc Technol 1: 26-40. DOI: https://doi.org/10.18091/ijsts.v1i2.9516.

61. Yoshizawa K (2006) Acc Chem Res 39: 375-382. DOI: 10.1021/ar050194t.

62. Rosa A, Ricciardi G (2012) Inorg Chem 51: 9833-9845. DOI: dx.doi.org/10.1021/ic301232r.

63. Tang H, Guan J, Zhang L, Liu H, Huang X (2012) Phys Chem Chem Phys 14: 12863-12874. DOI: $10.1039 / \mathrm{c} 2 \mathrm{cp} 42423 \mathrm{a}$.

64. Yang T, Quesne MG, Neu HM, Cantú Reinhard FG, Goldberg DP, de Visser SP (2016) J Am Chem Soc 138: 12375-12386. DOI: 10.1021/jacs.6b05027.

65. Sainna MA, Sil D, Sahoo D, Martin B, Rath SP, Comba P, de Visser SP (2015) Inorg Chem 54: 1919-1930. DOI: 10.1021/ic502803b. 
66. Latifi R, Bagherzadeh M, de Visser SP (2009) Chem Eur J 15: 6651-6662. DOI: 10.1002/chem.200900211.

67. Latifi R, Valentine JS, Nam W, de Visser SP (2012) Chem Commun 48: 3491-3493. DOI: $10.1039 / \mathrm{c} 2 \mathrm{cc} 30365 \mathrm{e}$.

68. de Visser SP, Ogliaro F, Shaik S (2001) Angew Chem Int Ed 40: 2871-2874.

69. Timmins A, Quesne MG, Borowski T, de Visser SP (2018) ACS Catal 8: 8685-8698.

70. Cho K-B, Hirao H, Shaik S, Nam W (2016) Chem Soc Rev 45: 1197-1210.

71. Sainna MA, Kumar S, Kumar D, Fornarini S, Crestoni ME,. de Visser SP (2015) Chem Sci 6: 1516-1529. DOI: 10.1039/C4SC02717.

72. Cantú Reinhard FG, Sainna MA, Upadhyay P, Balan GA, Kumar D, Fornarini S, Crestoni ME, de Visser, SP (2016) Chem Eur J 22: 18608-18619. DOI: 10.1002/chem.201604361.

73. Kaczmarek MA, Malhotra A, Balan GA, Timmins A, de Visser SP (2018) Chem Eur J 24: 5293-5302. DOI: 10.1002/chem.201704688.

74. NIST Chemistry WebBook, NIST Standard Reference Database, Number 69; Linstrom, P. J., Mallard, W. G., Eds.; National Institute of Standards and Technology: Gaithersburg, MD, 2016. http://webbook. nist.gov.

Table of Contents Graphic:

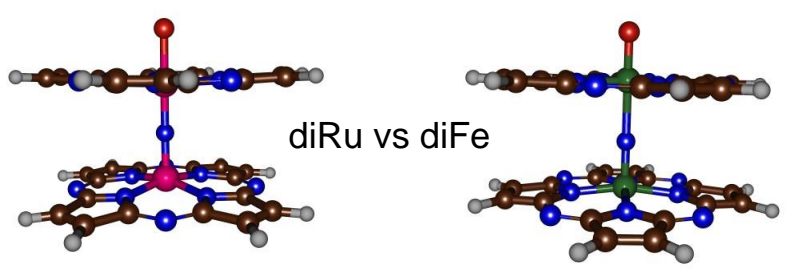

